\title{
Impact of Covid-19 on tourism-based livelihood of people in Small Island Developing Nation: Case study of A \& N Islands, India
}

\author{
Subhash Chand ${ }^{1}$, Abhishek Bharati ${ }^{2}$, Anurag Bharaty ${ }^{3}$ and Kingsly I T ${ }^{4}$
}

\begin{abstract}
:
In the past few decades, the tourism sector has emerged as a significant economic activity in island nations, particularly in tropical regions. However, most of the tropical islands face similar constraints. National and international tourists visit the SIDS including A \& N Islands and contribute to the GDP to significant share. The Covid-19 outbreaks in SIDs including A \& $\mathrm{N}$ islands shows that number of people infected were less as compared to metros or big cities. However, tourism activities completely stopped due to lockdown resulting in decreasing tourist's arrival, declined GDP and per capita income of SIDs to greater extent. The information gathered from various sources, mass media and net analysed and interpreted in this chapter. Due to Covid-19 tourist's arrival declined which has serious consequences on the livelihood of islander. Our analysis revealed A\&N Islands deficit in energy available at from different sources by $18.26 \%$. However, they are surplus in protein. The burden of high expenditure coupled with poor infrastructure make them more vulnerable in the circumstance of pandemic outbreaks. This outbreak has created the question of survival due to loss of jobs, halted economic activates, psychological, health unrest and livelihood threats among the depending people of these Island nations. Therefore, government interventions and subsidised package is very much essential to revive the tourism industry. The information given in this paper will be useful for future research and policy directions.
\end{abstract}

Key words: Island nations, Tourism, Small Island Nations, economic development, tropical islands.

\section{Corresponding author:}

1. Principal Scientist Ag. Economics, ICAR-National Institute of Agriculture Economics and Policy Research (NIAP), DPS Marg, P. B. No. 11305, Pusa, New Delhi-10012, India, schand46@gmail.com

\section{$\underline{\text { Associate authors: }}$}

2. Abhishek Bharati, (MBA), Researcher, Indian Institute of Management Jammu, India, mba19054@iimj.ac.in

3. Anurag Bharaty, Scholar, Agriculture Engineering, Ch. Charan Singh Agricultural University, Hisar, Haryana, India. anuragbharaty123@gmail.com.

4. Kingsly I T. Scientist Ag Economics, ICAR-National Institute of Agriculture Economics and Policy Research (NIAP), DPS Marg, P. B. No. 11305, Pusa, New Delhi-10012, India, k.immanuelraj@icar.gov.in 


\section{Impact of Covid-19 on tourism-based livelihood of people in Small Island Developing Nation: Case study of A \& N Islands, India}

\section{INTRODUCTION}

Corona virus is an infectious disease, which is caused by acute respiratory syndrome coronavirus. The diseased was found in December 2019 first time in Wuhan city of China. Gradually it has spread across the world and created a global pandemic situation. Presently Covid-19 been spread across the world and a global pandemic (>57 million infected 1.35 million deaths and 40.17 million recovered (as on World meter, 21/11/2020). Older peoples and peoples underlying with medical problems like, cancer, diabetes, cardiac illness, chronic respiratory illness is most likely to be affected with Covid-19. Some of infected people have already been recovered ( $>9$ million) but there were very high casualties ( $>1.0$ million). The pandemic has brought new clinical challenges combined with a potential increase in attendance to seriously unwell, dying and deceased patients, paramedics are likely to find themselves having to make critical clinical decisions [1]. This may result in moral injury where individuals experience thoughts relating to themselves and/or others that are negative and critical. This may lead to feelings of intense guilt, shame and/or blame. To feel this way, however, is a normal human response to a situation that is far from normal $[2,3,4,5,6]$ Covid-19 is really a serious pandemic and need to be taken extra care to deal with it. The tourism sector is currently one of the hardest-hit by the outbreak of Covid-19, with impacts on both travel supply and demand. This represents an added downside risk in the context of a weaker world economy, geopolitical, social and trade tensions, as well as uneven performance among major outbound travel markets. To enhance understanding of the characteristics of the Covid-19 (SARS-CoV-2) virus and the disease it causes, WHO has developed a series of early epidemiological protocols, the WHO Unity studies. The global international tourist arrivals could decline of $20 \%$ to $30 \%$ from an estimated growth of $3 \%$ to $4 \%$ forecast $[7,8]$. Further, tourism declined after more countries reported outbreaks and travel restrictions were implemented around the world [9]. Apart from the loss of lives this pandemic could cost the world $\$ 2.7$ trillion, equivalent to the UK economy [10]. Indicated that 50 million travel and tourism jobs are at risk [11], [12]. This could translate into a loss of US\$ 30 to 50 billion. Small and medium sized enterprises (80\% share) are expected to be particularly affected. Increased tourism last 30 years can be attributed to the emergence of middle class in the newly affluent and highly populated countries like China, Brazil and India [13]. Pandemic may spread very fast around the world by air travel more than 35000 airlines fly to more than 3500 cities hence many countries have suspended their 
flights[14]. This might affect livelihoods of millions across the world, including vulnerable communities who rely on tourism as a vehicle to their livelihood [15]. An estimated 113 million people around the globe were already persistently food insecure due to pre-existing shocks before the Covid-19 crisis (World Bank, 2020). Shortages in labour (through travel restrictions, morbidity, rules for social distancing) affect traders, producers, processors, and logistics in the food supply chain-mainly for food products where workers must be nearby [16,17]. Supply Chain Management: A majority of the developing nations faced supply disruption during the pandemic. Hence, appropriate interventions like strengthening the storage capacity for enhancing the buffer stock, processing [18], and distribution will help to counter the adverse situation. Decentralizing Food System: Promotion of a decentralized food system to make the emerging economies self-reliant and protecting the local food system. This also will help to facilitate in achieving a healthier food system [19] targeting the SDG2.

The impact of Covid-19 on travel, tourism, aviation and hospitality is to be serious. However, the impact has not been even across all industries. For instance, information communications technology (ICT) and its related industries have not felt the pinch as much as other industries [20]. Due to its crosscutting economic nature and deep social footprint, tourism is uniquely positioned to help societies and communities affected return to growth and stability. UNWTO calls for financial and political support for recovery measures targeting the tourism sector in the most affected countries. Doninc Lapinte, Benjamin, Dillette and Alderman [*] have indicated that halt and social distancing measures are made locals mobility impaired. Researchers pointed out the traveller activity shows some possibility of institutional innovation toward socializing tourism but the challenge will be in embedding the new normal for long term. This rebuilding has the potential regenerate short circuit economics, reinvigorate environmental hope and promote institutional innovation [21]. However, these small islands are having limited local population but these people also have to be protected and kept healthy. The impact of coronavirus on economy of small island nations also to be more serious due to fragile ecosystem and poor infrastructure base for some the islands. Since their livelihood depends on tourism sector and due to Covid-19, this sector is hard hit. The SIDS people are waiting for amicable solutions in pandemic era. Therefore, concern government should take policy decisions to revive their livelihood by subsidizing and relaxing economic benefits [2]. The Covid-19 pandemic and the measures put in place to contain its diffusion are taking a heavy toll on the tourism sector. Therefore, expected impact need to be worked out so that these islands may take the benefit of policy intervention and become capable in absorbing the shocks of pandemic. 
About India: India is fastest growing developing country with 3 trillion US dollar. India has fourth largest rail network, second largest internet user base, fourth largest in automobile industry, largest exporter of information technology and software services, second largest road network, significant role of pharma industry, infra industry, textile industry, restaurant industry also across the world. GDP contribution by the agriculture industry, manufacturing industry and service escort is 17 percent, 26 percent, 57 percent respectively. The Covid-19 has disrupted economic activities and the supply chains significantly. This is likely to have an impact on demand for agricultural products, dislocation of labour force and disruption of supply chains. The tourism sector attract the revenue from foreign (12.8\%) and domestic (87.2\%). This sector also employee huge number of people who drive their livelihood from this sector. The Indian tourism sector will also have the adverse effect of COVID-19. The Indian tourism industry is projected to book a revenue loss of Rs 1.25 trillion in calendar 2020 as a fall out of the shutdown of hotels and suspension in flight operations after the onset and spread of the coronavirus (Covid-19) pandemic. About 40 per cent decline in revenue over 2019. During April-June, the Indian tourism industry is expected to book a revenue loss of Rs 69,400 crore. The most visible and immediate impact of Covid-19 is seen in the hotel and tourism sector in all its geographical segments - inbound, outbound and domestic and almost all verticals. In India, most of the summer holiday bookings have also been cancelled (about 4050 per cent), thereby impacting domestic tourism. India's total foreign tourist arrivals stood at 10.9 million and the foreign exchange earnings stood at INR 210,971 crore during 2019, with Maharashtra, Tamil Nadu, Uttar Pradesh and Delhi accounting for about 60 per cent of foreign tourist arrivals 23 (The Economic Times). Countries ae having beautiful island ecosystem where in $\mathrm{A} \& \mathrm{~N}$ islands are very important from strategic point view for India. The topography of the A\&N islands is rolling with low range hilly mountains to narrow valley at the foothills resulting in an undulating terrain ranging from steep slopes to coastal plains. The A\&N group of Islands lie in the Bay of Bengal (6-14 ${ }^{0} \mathrm{~N}$ lat.; $92-94^{0} \mathrm{E}$ long.) with altitude ranging from 0 to $365 \mathrm{~m}$ above sea level. Average annual rainfall is $3100 \mathrm{~mm}$, distributed over 8-9 months. The A\&N islands house a total population of 3.8 lakh [24] with 82 percent literacy and home five indigenous tribe. The Gross State Domestic Products (GSDP) grew more than 5 percent during the last decade (2008 to 2019) though a notable slump was experienced during 2005-06 due to the earthquake followed by tsunami [25].

Agriculture sector provides considerable livelihood support to the local population in A\&N islands. Coconut occupies more than 50 percent of total cultivable area and is the main source of livelihood for the farming community [22,23]. Total milk production in the islands is about 
25.28 thousand tonnes [24], which is however constrained by poor veterinary services [25]. Total potential of marine fisheries is about 0.14 million tonnes and due to variety of constraints only 20 percent of the potential is being exploited [23]. Available estimates indicate that given the existing climate, land and water resources as well as technology, the islands can only meet the protein-calorie requirements of about 1.6 lakhs population and puts the maximum carrying capacity with advanced level of technologies at 2.5 lakhs population. Another estimate considering the potential of the ocean resources, places the carrying capacity at 8.5 lakh [30]. However, A \& N Islands of India has already crossed the potential limit. In recent past fast growing of tourism sector and expansion of tourism infrastructure witnessed that tourism sector is supporting livelihood of millions of people in SIDS including A \& N Islands. Due Covid19 , tourisms sector is standstill and people are unable to understand what to do. Therefore, we have chosen SIDS along with A \& N Islands of India for this study to understand the impact of Covid-19.

We argue that all the tourism activities will halt and wait for the signals from the respective government. With this background, the specific objectives of this paper are to review the information related to impact of Covid-19 on SIDs nations including A \& N Islands of India. To analyse the opinion of the researchers across the disciplines at global level about possible impact of Covid-19 on tourism industry. To understand the possible loss of revenue to the GDP of Island Nations? To analyse the declined tourists arrival in different islands particularly for A\& N Islands. We assume that these information will provide the idea and policy direction to address the different dimension of losses due Covid-19 and will provoke the researcher for further investigations.

\section{MATERIALS AND METHODS}

The various mass media, websites, newspapers and research articles were reviewed and their information used in this paper. Various aspects viz. share of tourism sector to the GDP, per capita income, number of infected people, recovery percent of infected people, impact on GDP contribution of tourism section in GDP, number of tourists arrived from 1995-2020, composition of tourists, etc., were covered. The vital indicators of Tropical Island Nations were compared with A\&N Island. The analysis has generated the background information to identify and explore specific issues related to impact of Covid-19, tourism development and the emerging scenario of tourism in A \& $\mathrm{N}$ islands. Employing the process of familiarisation and 
discovery, an in-depth understanding was developed on present and emerging dimensions of impact of Covid-19 on tourism. The end point of data on Covid-19 ending of August 2020. We are able to get the information on opinion of the people through telephonic conversations.

Analytical procedure: We have analyzed the data on number of Covid-19 cases, proportion to total population, test performed and recovery of Covid-19 patients for SIDs nations. We also have analyzed the data on SIDS fall in GDP, per capita income due to Covid-19, share of different small island developing nations economic activities for different islands. We have taken the methodology and data adopted by UNWTO. However, we attempted to provide initial information for thoughts provoking and policy arguments for small Islands development so that their shattered economy can be revived with better options. Qualitative data were entered into Stata-14 database and coded by thematic content. Our analysis focuses on both quantitative measures of difference and the descriptive inferences derived from the data. The opinions of different researchers across the SIDS nations were obtained though asking simple questions like, how do you perceive the impact of Covid-19 on tourism industry? What will be the possible way to revive this sector? We have analyzed the opinions of different research across the different countries and drawn the logical inferences as presented in subsequent sections. 


\section{RESULTS AND DISCUSSION}

The result section contains the opinion of researchers across the countries, status of Covid-19 -19 infection spread in SIDS, Economic activates and impact of Covid-19 on GDP and per capita income. The details of findings and interpretation are given as below.

Expected impact of Covid-19 (Perceptions): We have collected the information through mass media [31, 52,53,54] (https://www.researchgate.net/), by asking questions like what is the possible impact of Covid-19 on tourism sector. These researchers have expressed their opinion independently. It was learnt that majority of researcher felt that Covid-19 is going to be badly affecting the tourism industry and the livelihood of the people depend on it. Though some of the researchers have said that it is too early to comment on the actual impact of Covid19 but still for the time being this sector halted still and will take time to revive. We also feel the same and only option to revive this sector is the policy instrument, rebates and subsidies to tourism sector. It is not the question of revenue loss but the loss of employment, livelihood and idle infrastructure, these have incurred huge investment. This investment is not paying the dividends at the movement but cost and expenditure for maintenance and wearing tearing remain the same as before Covid-19. Therefore, this sector need special package and policy input to restart. The similar opinion of other researchers is given below. Many researcher like[32] says this pandemic opened the door of new opportunities. It has changed the thinking and investment behaviour of tour operators as well as the tourists. Some of the researchers have felt that tourism sector will suffer a big losses and will take many years to recover. Therefore, researcher still analysing and guessing about the impact of Covid-19. Majority of them are in opinion that tourism sector will face new challenges and constraints in future. Expectation on international tourist arrivals will be down. An expected fall of between 20-30\% could translate into a decline in international tourism receipts of between US\$300-450 billion, almost onethird of the US\$ 1.5 trillion generated in 2019 [33,48,49,50,51]. 
Table 1: The opinions of different researcher on impact of Covid-19 on tourism industry (As on 08/07/2020)

\begin{tabular}{|c|c|c|}
\hline Name of Researcher & $\begin{array}{l}\text { Organization/ } \\
\text { Institutions }\end{array}$ & Opinion of the researcher on possible impacts. \\
\hline Abhijit Mitra* & University of Calcutta & $\begin{array}{l}\text { The COVID-19 pandemic has virtually demolished all the previous narratives on } \\
\text { development. }\end{array}$ \\
\hline Akhmad Solikin* & $\begin{array}{l}\text { Polytechnic of State } \\
\text { Finance (STAN) }\end{array}$ & $\begin{array}{l}\text { As for tourism, Covid- } 19 \text { would reduce aviation and hotel sector by } 5 \% \text { and decrease } \\
\text { economic growth by } 0.09 \% \text {. }\end{array}$ \\
\hline $\begin{array}{l}\text { Anthonia Omotola } \\
\text { Ishabiyi* }\end{array}$ & $\begin{array}{ll}\text { University } & \text { of } \\
\text { KwaZulu-Natal } & \\
\end{array}$ & More likely to affect all sectors of economy. \\
\hline Anton Vrdoljak* & University of Mostar & Irrecoverable loss to tourism sector. \\
\hline Arvind Singh* & $\begin{array}{ll}\text { Banaras } & \text { Hindu } \\
\text { University } & \\
\end{array}$ & Agree to the loss of tourism sector. \\
\hline $\begin{array}{l}\text { Ayittei et al, } \\
2020 .[36]\end{array}$ & Researcher & Tourism is perhaps the main industry that would be negatively impacted \\
\hline Azizul Hassan* & $\begin{array}{lr}\text { University } & \text { of } \\
\text { Greenwich } & \\
\text { Business } & \text { School } \\
\text { London } & \\
\end{array}$ & $\begin{array}{l}\text { Research interests concentrate on technology supported marketing in tourism, } \\
\text { innovations in tourism marketing, heritage interpretation and sustainable marketing } \\
\text { alternatives for heritage tourism industries. }\end{array}$ \\
\hline B Koti Reddy* & $\begin{array}{l}\text { Department of Atomic } \\
\text { Energy }\end{array}$ & $\begin{array}{l}\text { It has a great impact on Tourism, but we have to manage for survival of dependent } \\
\text { people on tourisms. }\end{array}$ \\
\hline BBC News, 2020.* & Mass media & $\begin{array}{l}\text { Worries grow as cancellations increase and must be noticed that European visitors } \\
\text { to the island of Ireland spend about two billion euros, and it is a serious part of } \\
\text { national income. }\end{array}$ \\
\hline $\begin{array}{l}\text { Camilli M. (2020) } \\
{[35]^{*}}\end{array}$ & $\begin{array}{l}\text { ICOTEA Learning } \\
\text { Institute }\end{array}$ & $\begin{array}{l}\text { Analysed shows how massive it's the impact of the pandemic outbreak in the tourism } \\
\text { revenue. }\end{array}$ \\
\hline $\begin{array}{l}\text { CII Tourism } \\
\text { Committee }\end{array}$ & India & $\begin{array}{l}\text { Industry of Chamber CII, Covid-19, hit the Indian tourism industry impacting all its } \\
\text { geographical segments - inbound, outbound and domestic, almost all tourism } \\
\text { verticals - leisure, adventure, heritage, cruise, corporate and niche segments. } \\
\text { Government suspending, all visas and whole tourism value chain across hotels, } \\
\text { travel agents, destinations, restaurants, family entertainment venues and air, land and } \\
\text { sea transportation have been hit. }\end{array}$ \\
\hline Colin Sokol Kuka* & $\begin{array}{l}\text { The University of } \\
\text { York }\end{array}$ & $\begin{array}{l}\text { COVID-19 has destroyed tourism at the moment but it still unpredictable how people } \\
\text { will react when the lock-down measurements will be totally removed. }\end{array}$ \\
\hline $\begin{array}{l}\text { D A Gayan } \\
\text { Nayanajith* }\end{array}$ & University of Kelaniya & Tourism going to be badly affected due virus infections. \\
\hline $\begin{array}{l}\text { Dariusz } \\
\text { Prokopowicz* }\end{array}$ & $\begin{array}{lr}\text { Cardinal } & \text { Stefan } \\
\text { Wyszynski } & \text { University } \\
\text { in Warsaw } & \\
\end{array}$ & $\begin{array}{l}\text { Enterprises and companies operating in the tourist services sector entities has } \\
\text { recorded the largest decreases in orders, sales revenues and financial problems due } \\
\text { to Covid-19 pandemic. }\end{array}$ \\
\hline $\begin{array}{l}\text { Dariusz } \\
\text { Prokopowicz* }\end{array}$ & $\begin{array}{lr}\text { Cardinal } & \text { Stefan } \\
\text { Wyszynski } & \text { University } \\
\text { in Warsaw } & \end{array}$ & $\begin{array}{l}\text { There is a national recession in the countries where the tourism sector and related } \\
\text { services constitute a significant part of the whole economy. }\end{array}$ \\
\hline $\begin{array}{l}\text { Estrada et al, } \\
{[35] 2020^{*}}\end{array}$ & Researcher & Lead to a significant reduction in almost all global tourism. \\
\hline Fatih Günay* & Mersin University & Tourism sector will be affected a lot. \\
\hline $\begin{array}{l}\text { Federazione } \\
\text { Italiana del Turismo, } \\
\text { 2020.[37]* }\end{array}$ & Researcher & $\begin{array}{l}\text { In Italy, almost } 90 \% \text { percent of hotel and travel agency bookings for March } 2020 \\
\text { cancelled in Rome and up to } 80 \% \text { in Sicily. The impact is pushing economy back. }\end{array}$ \\
\hline Gary Joseph Ordog* & $\begin{array}{l}\text { County of Los Angeles } \\
\text { Public Health }\end{array}$ & Complete disaster until good A vaccine is developed. \\
\hline $\begin{array}{l}\text { Hassan Izzeddin } \\
\text { Sarsak* }\end{array}$ & $\begin{array}{l}\text { Batterjee Medical } \\
\text { College for Health Sci. } \\
\& \text { Technology }\end{array}$ & COVID-19 has been having a negative significant impact on tourism worldwide. \\
\hline Hassan Salehi* & $\begin{array}{l}\text { University of Southern } \\
\text { Queensland }\end{array}$ & $\begin{array}{l}\text { I think, there is no data outcome and we should wait until the end of this crisis. But } \\
\text { sometimes I hope big loss in terms of economics losses. }\end{array}$ \\
\hline Ismail Mondal* & Jadavpur University & The huge impact of tourism and economic sector of entire globe. \\
\hline Khan et al, 2009,* & Researcher & $\begin{array}{l}\text { A dangerous epidemic can spread very rapidly around the world by the air } \\
\text { transportations sector, using a network of } 35,000 \text { commercial airlines. }\end{array}$ \\
\hline $\begin{array}{l}\text { Lee \& McKibbin } \\
\text { [38], 2004* }\end{array}$ & Researcher & $\begin{array}{l}\text { Such kinds of pandemics affect directly industries such as tourism and retail service } \\
\text { sector. }\end{array}$ \\
\hline Lewis et al[31]. 2013 & Researcher & $\begin{array}{l}\text { Methods of assessing tourism preferences was employed. They pointedout that there } \\
\text { will be big loss. }\end{array}$ \\
\hline $\begin{array}{l}\text { Muhammed Ashraful } \\
\text { Alam* }\end{array}$ & $\begin{array}{l}\text { Ministry of Health and } \\
\text { Family Welfare, } \\
\text { Bangladesh }\end{array}$ & Just completely devastating the tourism industry. \\
\hline Nicholl[39], 2006* & Researcher & $\begin{array}{l}\text { In cases of pandemics, tourists cancel their travels avoiding suspect places and } \\
\text { people }\end{array}$ \\
\hline Nikki Ekstein* & Singapore & Can’t Fill \$20 Billion Tourism Gap. It will take time to recover. \\
\hline P. K. Karmakar* & Tezpur University & $\begin{array}{l}\text { Tourism sector will take time to recover. Strong government policy and stimulus } \\
\text { required. }\end{array}$ \\
\hline $\begin{array}{l}\text { Priyakrushna } \\
\text { Mohanty* }\end{array}$ & $\begin{array}{l}\text { Pondicherry } \\
\text { University India }\end{array}$ & $\begin{array}{l}\text { COVID-19 on different spheres of tourism and envisage the solutions which can put } \\
\text { tourism industry back on the paths of recover. }\end{array}$ \\
\hline
\end{tabular}




\begin{tabular}{|c|c|c|}
\hline $\begin{array}{l}\text { Rajkumar } \\
\text { Rajendram* }\end{array}$ & $\begin{array}{l}\text { King Saud bin Abdul- } \\
\text { Aziz University for } \\
\text { Health Sciences }\end{array}$ & In Saudi Arabia there is currently no tourism. \\
\hline Ramatu Ussif* & Anadolu University & Covid-19 has a strong negative effect on tourism. \\
\hline Rasha Shakir Nima* & University of Kufa & Tourism sector will be affected severely and recovery time will be long. \\
\hline $\begin{array}{l}\text { Reisinger \& } \\
\text { Mavondo, }[6] 2005 *\end{array}$ & Researcher & Rapid spread of the virus and the damage that can cause to health. \\
\hline Sadanand Pandey* & Yeungnam University & Asia being the most affected continent in terms of tourism sector loss. \\
\hline Sotiris Folinas* & University of Thessaly & Tourism is the great patient of Covid- 19. \\
\hline Subhash Chand* & $\begin{array}{l}\text { National Institute of } \\
\text { Agricultural } \\
\text { Economics and Policy } \\
\text { Research, India }\end{array}$ & $\begin{array}{l}\text { Impact of Covid-19 -19 people engaged will have to search for new livelihood } \\
\text { options and may not return back to tourism sector, may result in human resource } \\
\text { crisis. }\end{array}$ \\
\hline $\begin{array}{l}\text { Subhash Chavare* } \\
\text { Huge negative }\end{array}$ & K.G.D.B.L.M. Kundal & Impact of COVID-19 on tourism industry and it is difficult to over as early. \\
\hline $\begin{array}{l}\text { Syed Naimul } \\
\text { Wadood* }\end{array}$ & University of Dhaka & It would be difficult to bring back the former glory of tourism. \\
\hline $\begin{array}{l}\text { The United Nations } \\
\text { specialized agency } \\
\text { for tourism, 2020 }\end{array}$ & $\begin{array}{ll}\text { United } & \text { Nation } \\
\text { Organization } & \end{array}$ & $\begin{array}{l}\text { Taking into account past market trends, this would mean that between five and seven } \\
\text { years' worth of growth will be lost to Covid-19 (UNWTO, 2020). }\end{array}$ \\
\hline $\begin{array}{l}\text { World Economic } \\
\text { Forum[40], } 2020\end{array}$ & Mass media & $\begin{array}{l}\text { When the outbreak will be over, it could take up to ten months for the industry to } \\
\text { recover. }\end{array}$ \\
\hline World meters, $2020 *$ & Researcher & Increased the infected cases are continue. \\
\hline Zurab Pololikashvili* & $\begin{array}{l}\text { Secretary General } \\
\text { UNWTO }\end{array}$ & $\begin{array}{l}\text { The restart of tourism means return of hope and opportunity for many millions of } \\
\text { people around the world. }\end{array}$ \\
\hline
\end{tabular}

Status of Covid-19 infections in SIDS nations including A \& N Islands: Status of Covid-19 in SIDS: The tourism industry has always been one of industries hardest hit by pandemics and crises. Throughout history, the industry has borne the brunt of major pandemics and plagues, notably, the Black Death (1346-1353), Spanish Flu (1918-1920), SARS (2002-2004), H1N1 Swine Flu (2009-2010) and Ebola Virus (2014-2016). The Spanish flu for instance, restricted travel for four months and killed 21 million people during that short period. The swine flu pandemic led to the Mexican tourism industry alone losing almost a million overseas visitors over a five-month period which translated into losses of about US $\$ 2.8$ billion. The World Health Organization also issues travel advisories to discourage travel to destinations with cases of pandemics. Airlines, tour operators, travel agents, attraction sites, car hire, restaurants and hotels have been adversely impacted. All businesses and service providers along the tourism value chain including the farmer who supplies vegetables to a restaurant and a taxi driver who shuttles tourists from the airport to hotels are all affected.

With above background we have collected the information provided on https://www.worldometerinfo/coronavirus/ on Covid-19 and analyzed for SIDS only and same is presented in table 2 . The data on number of cases reported, total deaths, recovery rate and tests performed shown in this table as on 22/10/2020 for these islands. The SIDS are mostly having fragile agro ecological coastal system where in biodiversity is rich that posed current threats due to biotic interferences. The Covid-19 infected data shows that these islands are 
having less number of affected peoples as compared to metro cities. However, the expectation of infections may be very high due outsider's movement if tourism is opened. Since government has taken serious steps of lockdown, this might has resulted in less number of affected people in SIDSs. Further, less number of infected people does not mean these islands are safe. It is because, their facilities and health infrastructure is also not so good. Therefore, Covid-19 is really a serious pandemic and need to be taken extra care to dealt with it. Though, these islands having limited local population but these people also have to be protected and kept healthy.

Table 2: Status of Covid-19 cases in small Island nations (As on 22/10/2020)

\begin{tabular}{|c|c|c|c|c|c|c|c|c|c|}
\hline Island nations & $\begin{array}{l}\text { Total } \\
\text { Cases }\end{array}$ & $\begin{array}{l}\text { Total } \\
\text { Deaths }\end{array}$ & $\begin{array}{l}\text { Total } \\
\text { Recovered }\end{array}$ & $\begin{array}{l}\text { Active } \\
\text { cases }\end{array}$ & $\begin{array}{l}\text { Serious } \\
\text { Critical } \\
\text { cases }\end{array}$ & $\begin{array}{l}\text { Death/1M } \\
\text { pop }\end{array}$ & Total Tests & $\begin{array}{l}\text { Tests/1M } \\
\text { pop }\end{array}$ & $\begin{array}{l}\text { Population } \\
\text { (N0.) }\end{array}$ \\
\hline India & $7,706,946$ & 116,653 & $6,874,518$ & 715,775 & 8,944 & 84 & $98,670,363$ & 71,285 & 1384160060 \\
\hline $\begin{array}{lr}\text { Andaman } & \text { and } \\
\text { Nicobar } & \text { Islands, } \\
\text { India } & \end{array}$ & 199 & 56 & & 3,913 & & & & & 387000 \\
\hline Antigua and Barbuda & 122 & 3 & 101 & 18 & & 31 & 3,260 & 33,205 & 98178 \\
\hline Barbados & 222 & 7 & 205 & 10 & & 24 & 31,534 & 109,690 & 287484 \\
\hline Cabo Verde & 8,033 & 90 & 6,835 & 1,108 & 23 & 161 & 87,480 & 156,821 & 557834 \\
\hline Cayman Islands & 235 & 1 & 214 & 20 & 1 & 15 & 44,724 & 678,068 & 65958 \\
\hline Channel Islands & 775 & 48 & 659 & 68 & 2 & 275 & 138,993 & 797,188 & 174354 \\
\hline Comoros & 504 & 7 & 494 & 3 & & 8 & & & 875181 \\
\hline Dominica & 33 & & 29 & 4 & & & 3,955 & 54,899 & 72041 \\
\hline Faeroe Islands & 488 & & 473 & 15 & & & 147,786 & $3,020,973$ & 48920 \\
\hline Falkland Islands & 13 & & 13 & 0 & & & 2,682 & 764,103 & 3510 \\
\hline Fiji & 33 & 2 & 30 & 1 & & 2 & 12,125 & 13,496 & 898442 \\
\hline Grenada & 27 & & 24 & 3 & & & 6,252 & 55,483 & 112684 \\
\hline Iceland & 4,230 & 11 & 3,013 & 1,206 & 3 & 32 & 331,351 & 969,078 & 341924 \\
\hline Jamaica & 8,445 & 174 & 4,016 & 4,255 & 10 & 59 & 90,008 & 30,355 & 2965156 \\
\hline Lakshadweep & 44 & 2 & & 3,161 & & & & & \\
\hline Madagascar & 16,810 & 238 & 16,215 & 357 & 16 & 9 & 85,407 & 3,061 & 27904012 \\
\hline Maldives & 11,316 & 37 & 10,284 & 995 & 12 & 68 & 150,743 & 277,393 & 543428 \\
\hline Philippines & 362,243 & 6,747 & 311,506 & 43,990 & 1,562 & 61 & $4,450,230$ & 40,447 & 110025607 \\
\hline Saint Kitts and Nevis & 19 & & 19 & 0 & & & 2,828 & 53,043 & 53315 \\
\hline Saint Lucia & 38 & & 27 & 11 & & & 9,472 & 51,510 & 183886 \\
\hline Saint Martin & 538 & 8 & 422 & 108 & 12 & 206 & 6,072 & 156,229 & 38866 \\
\hline Saint Pierre Miquelon & 16 & & 12 & 4 & & & 2,222 & 384,097 & 5785 \\
\hline San Marino & 774 & 42 & 690 & 42 & 2 & 1,237 & 8,830 & 260,065 & 33953 \\
\hline $\begin{array}{l}\text { Sao Tome and } \\
\text { Principe }\end{array}$ & 935 & 15 & 898 & 22 & & 68 & 5,755 & 26,113 & 220390 \\
\hline Seychelles & 151 & & 148 & 3 & & & 5,200 & 52,774 & 98534 \\
\hline Singapore & 57,933 & 28 & 57,821 & 84 & & 5 & $3,486,260$ & 594,471 & 5864473 \\
\hline Sri Lanka & 5,978 & 13 & 3,501 & 2,464 & & 0.6 & 415,243 & 19,367 & 21440962 \\
\hline Trinidad and Tobago & 5,392 & 101 & 3,822 & 1,469 & 14 & 72 & 31,846 & 22,733 & 1400889 \\
\hline Indonesia & 373,109 & 12,857 & 297,509 & 62,743 & & 47 & $4,167,210$ & 15,186 & 274408594 \\
\hline World & 41487185 & 1136341 & 30427891 & 7817920 & 74170 & 29296.28 & 755525782 & 37610079 & 7782065688 \\
\hline Mean & 1614606 & 55369 & 1311082 & 279347 & 6521 & 1512 & 30997272 & 1654329 & 331550004 \\
\hline Standard deviation & 7527820 & 236891 & 5742871 & 1404980 & 20475 & 6372 & 143204268 & 7072020 & 1456234141 \\
\hline
\end{tabular}

Source: https://www.worldometerinfo/coronavirus

On an average 1.61 million people were affected in the world including SIDS. The average death was more than 56 million. The recovery percent was very high for SIDS nations, which is good sign of combating with the deadly pandemic. Among the SIDs nations, highest 
death was recorded for Indonesia followed by Madagascar, Philippines and other SIDs nations (Table 3). However, these islands are having less number of causalities but still it is very high in relative term since their population is very small. Another reason could be poor infrastructure for testing facilities.

Therefore, concern government should take policy decisions to revive their livelihood by subsidizing and relaxing economic benefits [2]. The Covid-19 pandemic and the measures put in place to contain its diffusion are taking a heavy toll on the tourism sector. According to the United Nations World Tourism Organization (UNWTO), the Covid-19 pandemic will result in a contraction of the tourism sector by $20 \%$ to $30 \%$ in 2020 . According to the World Travel and Tourism Council (WTTC), in previous viral epidemics the average recovery time for visitors to a destination was about 19 months [30].

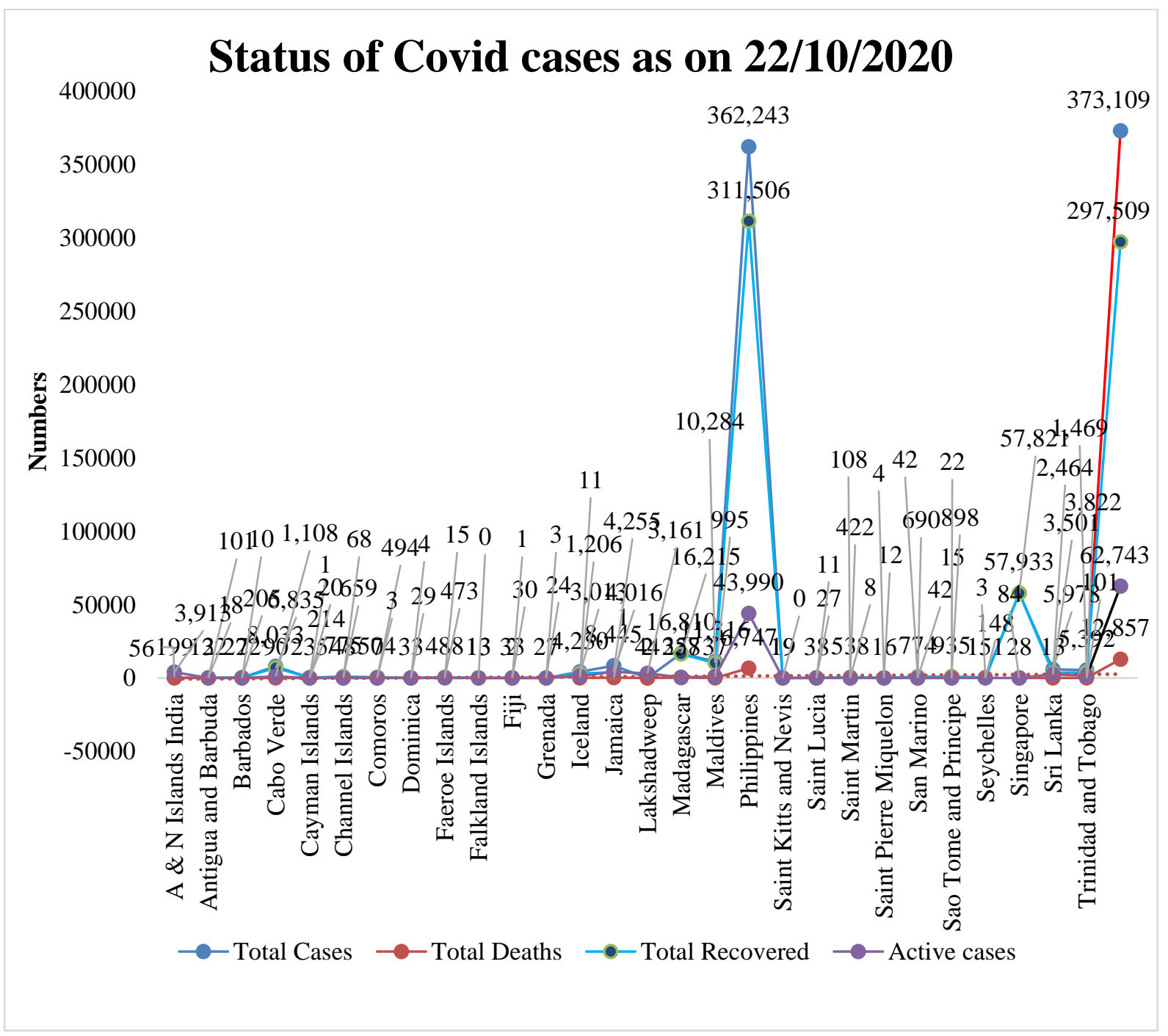

Source: https://www.worldometerinfo/coronavirus 
Impact on economy of small Islands: The sudden, deep and likely prolonged downturn in the travel and tourism sector has made countries that rely heavily on foreign tourism very concerned about their finances. Among these, Small Island Developing States (SIDS) are most vulnerable because not only they are highly dependent on tourism, but also because any shock of such magnitude is difficult to manage for small economies. Most of the tropical island nations had economic activities like tourism, agriculture and fishing, timber and food processing and manufacturing industries. However, A \& N Islands also highly dependent on service sector (56\%) followed by agriculture and tourism. It was observed that, in some of the island nations, tourist's inflow was more than the local population as is the case of Singapore (194\%), Barbados (193\%) and Seychelles (157\%) before Covid-19 and it is assumed zero. In A \& N Islands, this ratio was much lower at $41 \%$, but these islands were growing with faster rates. However, due to Covid-19 lockdown and restrictions, now completely switched off. On average, the tourism sector accounts for almost $30 \%$ of the gross domestic product (GDP) of the SIDS, according to WTTC data. This share is over $50 \%$ for the Maldives, Seychelles, St. Kitts and Nevis and Grenada. Overall, travel and tourism in the SIDS generates approximately $\$ 30$ billion per year. A decline in tourism receipts by $25 \%$ will result in a $\$ 7.4$ billion or 7.3\% fall in GDP. According to the updated IMF forecasts from 14th April 2020, due to the outbreak of the Covid-19, GDP growth is expected to fall to $-6.8 \%$ in 2020 and pick up to $5.9 \%$ in 2021, subject to the post-pandemic global economic recovery. The drop could be significantly greater in some of the SIDS, reaching $16 \%$ in the Maldives and Seychelles. It is expected that for many SIDS, the Covid-19 pandemic will directly result in record amounts of revenue losses without the alternative sources of foreign exchange revenues necessary to service external debt and pay for imports. In general, countries may be able to weather economic storms by relying on additional debt or using available foreign reserves. However, access to global capital markets is increasingly tight, more for small countries such as SIDS, which are often highly indebted and not well diversified. The external debt of the SIDS as a group accounts for $72.4 \%$ of their GDP on average, reaching up to $200 \%$ in the Seychelles and the Bahamas. Given these statistics, it is evident that without international assistance, the economic consequences of the pandemic will be devastating for many of the SIDS particularly those depend on tourism sector.

Impact of Covid-19 on per capita income: The per capita income of island nations compared was found to be much higher than A \& N Islands to the tune of 300 to 7800 percent. It is 
interesting to note that literacy rate was found to be very high in all the tropical islands, the lowest being $82 \%$ (Table 3 ).

Table 3: Impact of Covid-19 on small Island Nations tourism, GDP and per capita income

\begin{tabular}{|c|c|c|c|c|c|c|c|c|c|}
\hline \multirow[t]{2}{*}{$\begin{array}{l}\text { Name } \\
\text { islands }\end{array}$} & \multirow{2}{*}{$\begin{array}{l}\text { Area } \\
(00 \quad \mathrm{Sq} . \\
\mathrm{km})\end{array}$} & \multirow[t]{2}{*}{ Major economic activity } & \multirow{2}{*}{$\begin{array}{l}\text { Touris } \\
\mathrm{m} \% \text { to } \\
\text { GDP }\end{array}$} & \multirow{2}{*}{$\begin{array}{l}\text { Extern- } \\
\text { al debt } \\
(\%)\end{array}$} & \multirow{2}{*}{$\begin{array}{l}\text { Agri. } \\
\text { Share } \\
(\text { GDP\%) }\end{array}$} & \multirow{2}{*}{$\begin{array}{l}\text { Services } \\
\text { Sector share } \\
(\text { GDP \%) }\end{array}$} & \multirow{2}{*}{$\begin{array}{l}\text { Per capita } \\
\text { income } \\
(\$)\end{array}$} & \multicolumn{2}{|c|}{$\begin{array}{l}\text { Falls due to Covid-19 } \\
-19\end{array}$} \\
\hline & & & & & & & & $\begin{array}{l}\text { GDP } \\
(\%)\end{array}$ & $\begin{array}{l}\text { per capita } \\
\text { income }(\$)\end{array}$ \\
\hline $\begin{array}{l}\text { Andaman \& } \\
\text { Nicobar } \\
\text { islands India }\end{array}$ & 82.5 & Tourism, Service, agriculture & 18 & $3.8^{*}$ & 36.1 & 48.9 & 945.8 & 25 & 709.35 \\
\hline $\begin{array}{l}\text { Antiqua and } \\
\text { the Barbuda }\end{array}$ & 4.4 & Tourism, agriculture & 45 & 34 & 3.8 & 74.3 & 18300 & 11 & 16287 \\
\hline Bahamas & 4.3 & Tourism, sugar & 40 & 194 & 6 & 58.4 & 18900 & 10 & 17010 \\
\hline Barbados & & Tourism, agriculture & 36 & 29 & & & 18534 & 9 & 0 \\
\hline Cabo Vede & 40.3 & Fuel, shoes, garments, fish & 46 & 89 & 9 & 73.9 & 7000 & 12 & 6160 \\
\hline Comoros & 22.4 & $\begin{array}{l}\text { Cash crops (vanilla, ylang- } \\
\text { ylang into perfume) }\end{array}$ & 10 & 17 & 40 & 56 & 600 & 3 & 582 \\
\hline Dominica & 7.5 & Agriculture, tourism, soap & 38 & 55 & 17.7 & 32.8 & 3800 & 10 & 3420 \\
\hline Fiji & 182 & $\begin{array}{l}\text { Sugar, coconut oil, fish, timber, } \\
\text { garments, gold, }\end{array}$ & 40 & 17 & 8.9 & 77.6 & 4100 & 10 & 3690 \\
\hline $\begin{array}{l}\text { Fed. States } \\
\text { Micronesia }\end{array}$ & 7.1 & Agriculture, fisheries & 6.2 & 30 & 28.9 & 55.9 & 2300 & & 1886 \\
\hline Grenada & 3.5 & Tourism and agriculture & 56 & 59 & 5.4 & 62 & 3900 & 14 & 3354 \\
\hline Jamaica & 108.3 & $\begin{array}{l}\text { Services, tourism, remittances } \\
\text { and bauxite/alumina }\end{array}$ & 35 & 108 & 5 & 61 & 4800 & 9 & 4368 \\
\hline Kiribati & 7.3 & Copra, fish, tourism & 19 & 8 & 8.9 & 66.8 & 3600 & 5 & 3420 \\
\hline Madagascar & 5870 & Agriculture, fisheries, forestry & & 35 & 26.8 & 57.4 & 900 & & 684 \\
\hline Maldives & 3 & Tourism, fisheries & 66 & 48 & 16 & 77 & 4600 & 17 & 3818 \\
\hline $\begin{array}{l}\text { Marshall } \\
\text { Islands }\end{array}$ & 1.8 & $\begin{array}{l}\text { Copra cake, coconut oil, } \\
\text { fisheries, handicrafts }\end{array}$ & 9 & 52 & 31.7 & 53.4 & 2900 & 2 & 2842 \\
\hline Mauritius & $2,0.40$ & $\begin{array}{l}\text { Tourism, financial services, } \\
\text { retail and wholesale trade }\end{array}$ & 24 & 72 & 45 & 68.5 & 23,699 & 6 & $\overline{0}$ \\
\hline $\begin{array}{l}\text { Micronesia, } \\
\text { fed. Sts. }\end{array}$ & 7.02 & $\begin{array}{l}\text { Agri. Industry and service } \\
\text { sector }\end{array}$ & 8 & 29 & 21 & 62.8 & 3,400 & 2 & $\overline{0}$ \\
\hline Nauru & 0.2 & Exports of phosphates & 1 & 22 & 5 & 15 & 5000 & 0 & 4350 \\
\hline Palau & 4.6 & $\begin{array}{l}\text { Tourism, subsistence } \\
\text { agriculture, fisheries }\end{array}$ & 43 & 31 & 6.2 & 81.8 & 7600 & 11 & 6764 \\
\hline Philippines & 3000 & $\begin{array}{l}\text { Copper, petroleum products, } \\
\text { coconut oil, fruits }\end{array}$ & 12.7 & 22 & 13.8 & 54.5 & 3200 & & 2720 \\
\hline $\begin{array}{l}\text { Sao Tome and } \\
\text { Principe }\end{array}$ & 9.6 & Cocoa production & 27 & 59 & 14.9 & 71 & 1600 & 7 & 1488 \\
\hline Seychelles & 4.5 & Tourism & 66 & 198 & 2.1 & 69.6 & 16600 & 16 & 13944 \\
\hline Singapore & 7.1 & $\begin{array}{lll}\begin{array}{l}\text { Exports } \\
\text { products) }\end{array} & \text { (electronics, } & \text { IT } \\
\end{array}$ & 418.3 & & 0 & 68.8 & 49990 & & 36493 \\
\hline Samoa & 28.3 & Agriculture, fisheries & 23 & 51 & 11.4 & 30.2 & 5400 & 6 & 5076 \\
\hline $\begin{array}{l}\text { Solomon } \\
\text { Islands } \\
\end{array}$ & 289 & Agriculture, fisheries, forestry & 13 & 29 & 42 & 47 & 1900 & 3 & 1843 \\
\hline Sri Lanka & 656 & $\begin{array}{l}\text { Food processing, beverages, } \\
\text { textiles, port construction }\end{array}$ & 13 & 68 & 11.7 & 58.4 & 4000 & & 3280 \\
\hline St. Lucia & 6.2 & $\begin{array}{l}\text { Tourism, industries, offshore } \\
\text { banking }\end{array}$ & 43 & 35 & $\overline{5}$ & 53.6 & 4800 & 11 & 4272 \\
\hline $\begin{array}{l}\text { St. Vincent and } \\
\text { the grenadines }\end{array}$ & 3.9 & Agricultural, tourism & 46 & 38 & 10 & 64 & 9800 & 12 & 8624 \\
\hline $\begin{array}{l}\text { St. kitts \& } \\
\text { Nevis }\end{array}$ & 2.7 & Tourism, manufacturing & 63 & 20 & 3.5 & 70.7 & 13900 & 16 & 11676 \\
\hline Timor Lasselle & 148.74 & Oil and gas reserves & 3 & 7 & 15 & & 1,295 & 1 & 0 \\
\hline Tonga & & $\begin{array}{l}\text { Agriculture, Industry and } \\
\text { service }\end{array}$ & 21 & 41 & 17 & 12 & 6,520 & 5 & 0 \\
\hline $\begin{array}{l}\text { Trinidad and } \\
\text { Tobago }\end{array}$ & 51.3 & Oil, gas, petrochemicals & 8 & 30 & 0.6 & 37.4 & 21700 & 2 & 21266 \\
\hline Tuvalu & 0.26 & Sale of stamps & 6 & 45 & 16.6 & 56.2 & 1600 & 2 & 1568 \\
\hline Vanuatu & & Agril and service sector & 48 & 46 & 15 & 40 & 2,862 & 12 & 0 \\
\hline
\end{tabular}

Source: UNCTAD based on data from UCTAD State WTTC, World Bank, IMF, FAO and national statistics. Aggregates figures are GDP weighted averages. SIDS are defined according to the UCTAD classification, Agriculture census report (2001), Directorate of economics and statistics, A \& N Administration, Port Blair, Basic statistics (Various issues),Department of forest and environment (various issues).

Note: *indicate the external debt \% to GDP for India

The area under agriculture was found to be in the range of $12 \%$ to $35 \%$ and it was higher as compared to A\&N islands [42,55]. However, due to decline in number of tourist's arrival the 
per capita income as well as GDP will decline for these island nations very sharply due to Covid-19. The recovery will take time may be $2-5$ years at same level of tourism industry during 2018-19.Therefore, SIDS island nations are more vulnerable and prone to be at high risk due to Covid-19.

It is due to geographical locations, poor infrastructure, poor resource base, fragile agro ecosystem and high dependency on service sector. Hence, SIDS are going to be hard hit by this pandemic. The government interventions with special package may reduce the vulnerability of these nations.

Tourism development policy for A \& N Islands: The government expenditure on tourism development experienced a steady increase during the past 6 decades. The share of tourism expenditure in total outlay remained less than 1 per cent till the seventh plan, but experienced considerable hike in the succeeding plans reaching at 2.15 per cent. The revenue generation through tourism activities from 1991 to 2014, improved except the year of 2005-06 (after tsunami). Thereafter, revenue received more than 2200 crores per annum. The guesthouses operated by the Andaman Administration provide boarding facilities in addition to that offered by nearly 100 private hotels/ resorts. India's first seaplane was recently introduced for the tourists and local people. Helicopter service is already in operation for inter-island movements, which goes to 18 destinations daily.

Effect on tourists Inflow due to Covid-19 in A \& N Islands: India is ranked 65th out of 144 countries in the World Economic Forum Travel \& Tourism Competitiveness Report 2013, 2020. Tourism sectors are estimated to contribute 6.23 percent to the GDP and about 9 percent to the total employment.

\section{India's Visitor Arrivals:}

Foreigner: The tourist spots in A \& $\mathrm{N}$ islands are located in two districts of the island are includes Havelock island, Campaign facilities, Neil Island, Rose \& Smith Island, carbyn's cove, Good Will Estate, Scuba dive centre at Wandoor, Island Trade Fare Exhibition ground etc. Other facilities include Mahatma Gandhi National Marine Park, Mt. Harriet NP, lime stone cave, mud volcano, Biological Park at Chidiyatappu, etc. These island nations further can be better tourist spots and may harvest the opportunities for improving livelihood of the islands [23]. The performance study of tourism sector in Hong Kong revealed the similar observations [31]. The tourist inflow was also observed to be extremely higher in the case of neighbouring nations. Some of smaller island nations ( $<1000$ sq.km. area) were found to be better. Recently government of Indian also recognised the importance of tourism and has identified nine islands 
will be developed like Singapore [Error! Reference source not found.]. It could be observed that tourists arrival from different destinations have shown an increasing trend from 1995-96 2004-05 \& 2006-07 to 2019. It could be noted that during 1995-96 total tourist inflow was very low (<0.04 million). However, during 1995-2004 the inflow increased sharply. Government of India also recognised tourism sector is important livelihood supporting sector and emerging in big way (Govt. of India, 2001). Due to Covid-19, tourist's arrival assumed to be zero for the year of 2020 for SIDS and A \& N islands as well. The trend of tourist's arrival for domestic and foreign is depicted on fig. 1 for A \& N Islands. Since 1995 to 2019, there was sharp increase in the arrivals but during Covid-19 it is being completely stopped. This is matter of concern and need urgent attention of the policy maker. Hence, similar is the trend of SIDS nations. Therefore, tourism sector need to be revived with proper policy instrument. These emerging scenarios would have considerable bearing on future demand and supply patterns of agriculture products particularly food items. The decreased tourist's arrival will have impact on local food security due to Covid-19 and it could be inferred that before Covid-19 most of the SIDSs were depending upon food imports. There was big gap in demand and supply of local production. Now many items will be surplus or there will be deficiency at local level due to lockdown. However, the livelihood of the people of these islands will suffer measurably. Therefore, respective government need to have some relaxation/ subsidy policy for these islands for survival of islands. The SIDS may also experiencing similar constraints during pandemic. Therefore, international level support to the tourism industry is very much required.

In A \& N Islands of India, tourist's information is presented in fig.2. It can be inferred from the figure that Up to 2019 tourist's inflow was showing an increasing trend. However, since Covid-19 spread the tourist's inflow has become almost zero. This is shown with downward flatten the graph in the figure. This as big loss to locals as well as to state administration. Still there is no hope for its revival since, Covid-19 spread at higher rate in the country (Directorate of Economic \& Statistics, various issues, and Forest Statistics various issues). 


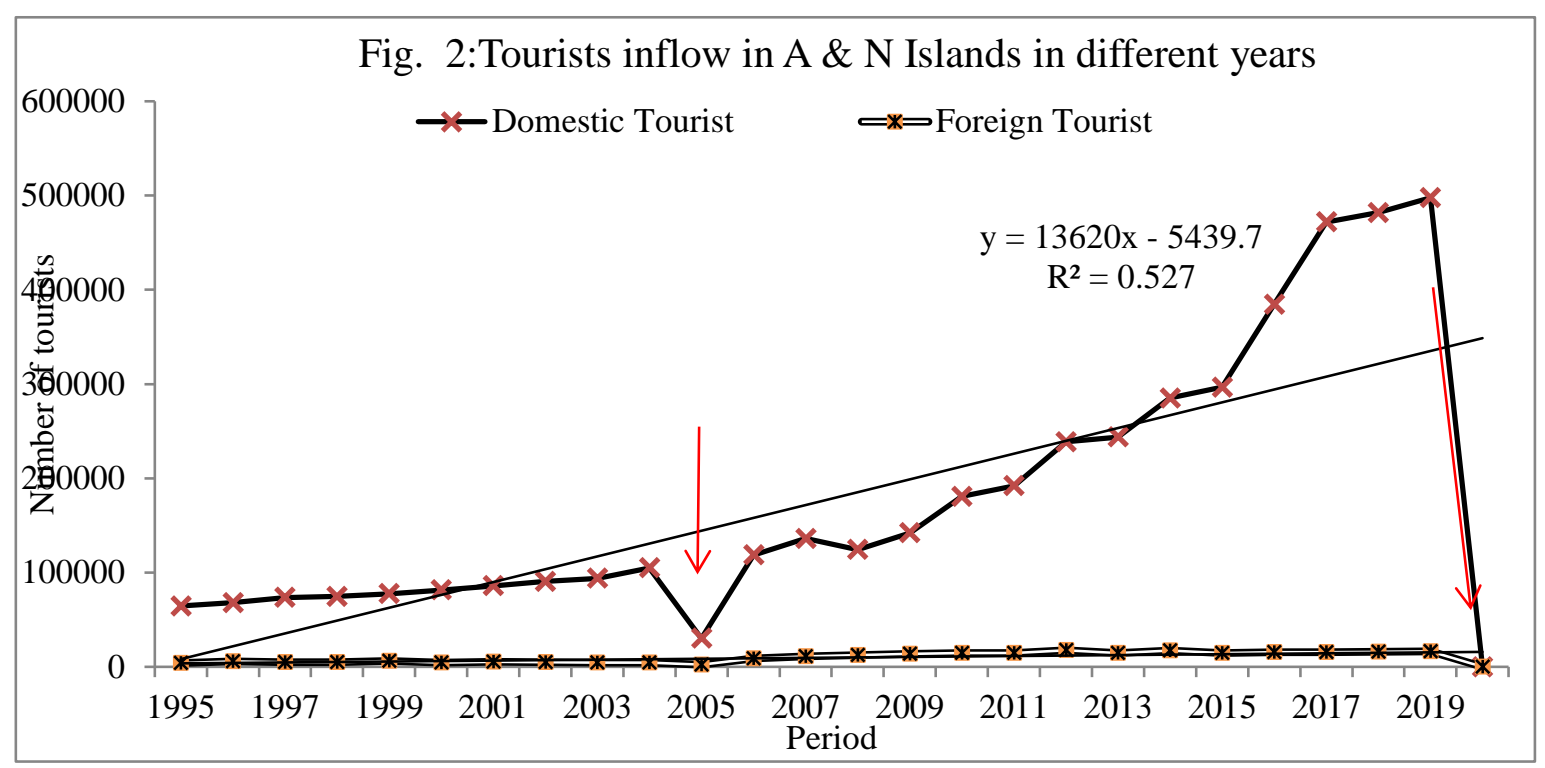

Source: Directorate of Economics and statistics, A \& N Administration, Port Blair (Various issues)

Source: Department of Economics and Statistics, A \& N Administration various issues

Impact on social events: The social events like organization of festival events, annual sports even crop harvesting festivals were cancelled due to fear of Covid-19. Figure 3. indicate the chronology of events organized by tribal communities of Andaman and Nicobar islands.

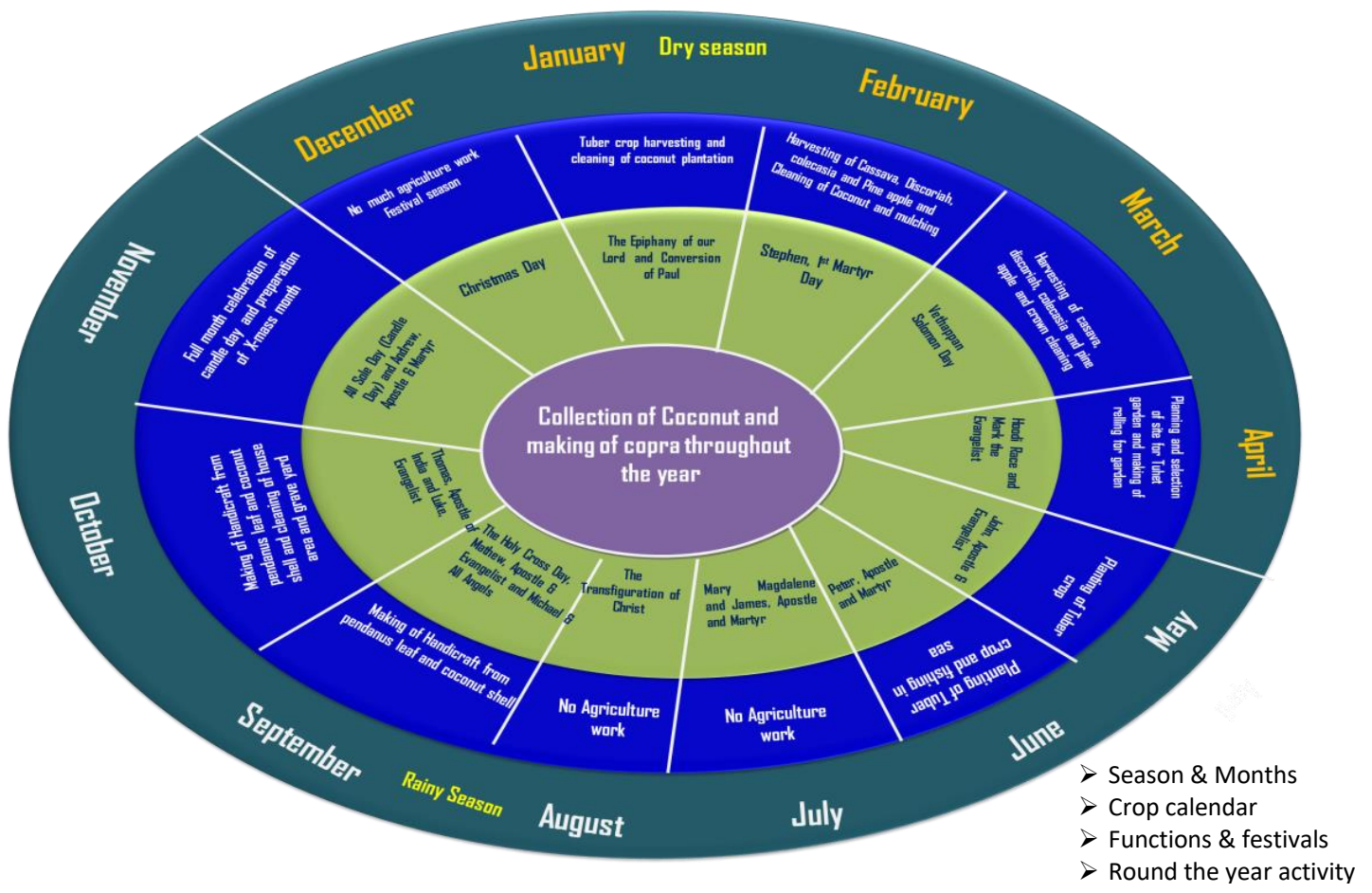

Figure 3: Showing the round the year events organized by the tribal 
The tribal of these islands keep on engaged themselves in different social events round the year along with agriculture and other livelihood activities. Due to fear of Covid-19 they are forced to cancel their cultural festival events. Table 4 indicate the cancelled month wise events. Through telephonic conversation, it was informed that there is no certainty when they will be able to organize these functions again. Therefore, Covid-19 has affected the livelihood of these people and had greater impact on livelihood management. The social events organization is the part of life for the tribal as well as for the islanders, which keep them busy throughout the year. By organizing these festivals and social gathering themselves healthy and active. Now many tribal youth are expressing psychological disorder. It was informed that we do not find any activity to pass time. Therefore, many people becoming unhealthy. If this trend is continued, many more people will unhealthy.

Table 4: Status of social events halted due to Covid-19

\begin{tabular}{|c|c|c|c|c|c|c|}
\hline \multirow[t]{2}{*}{ Months } & \multirow[t]{2}{*}{ Name of event } & \multirow[t]{2}{*}{ Season } & \multirow{2}{*}{$\begin{array}{l}2018- \\
19\end{array}$} & \multirow[t]{2}{*}{$2019-2020$} & \multicolumn{2}{|c|}{ Peoples opinion $n=68$} \\
\hline & & & & & Yes (\%) & No $(\%)$ \\
\hline January & $\begin{array}{l}\text { Epiphany of lord and } \\
\text { conversion of Paul }\end{array}$ & Dry & In time & Cancelled & 98 & 2 \\
\hline February & $\begin{array}{l}\text { Stephen Is martyr day } \\
\text { Nicobar trade fare, } \\
\text { Islands trade fare }\end{array}$ & Dry & In time & Cancelled & 91 & 9 \\
\hline March & Vethappan Solomon day & Dry & In time & Cancelled & 96 & 4 \\
\hline April & $\begin{array}{l}\text { Hoody race and mark the } \\
\text { evangelist }\end{array}$ & Dry & In time & Cancelled & 92 & 8 \\
\hline May & $\begin{array}{l}\text { John apostle and } \\
\text { evangelist }\end{array}$ & Rainy & In time & Cancelled & 95 & 5 \\
\hline June & Peter apostle and Martyr & Rainy & In time & Cancelled & 97 & 3 \\
\hline August & $\begin{array}{l}\text { Marry Magdalene, Jams } \\
\text { Apostle and martyr }\end{array}$ & Rainy & In time & Cancelled & 94 & 6 \\
\hline September & $\begin{array}{l}\text { The transformation of } \\
\text { Christ }\end{array}$ & Rainy & In time & Cancelled & 99 & 1 \\
\hline October & $\begin{array}{l}\text { The Holi cross day, } \\
\text { Mathew apostle, } \\
\text { evangelist, Michal and all } \\
\text { angels. }\end{array}$ & Rainy & In time & Cancelled & 98 & 2 \\
\hline November & $\begin{array}{l}\text { Thomas apostle of India } \\
\text { and evangelist }\end{array}$ & Rainy & In time & Cancelled & 96 & 4 \\
\hline December & $\begin{array}{l}\text { All Solomon day and } \\
\text { Andrew apostle and } \\
\text { martyr }\end{array}$ & Rainy & In time & Cancelled & 89 & 11 \\
\hline
\end{tabular}

Source: Authors observation though telephonic conversation

The main reason for this is no option available to keep them engaged being small island ecosystem. Therefore, in hygienic manner they may be allowed to organize their local festivals. 
More than 90 percent people have informed that all major annual events were cancelled. However, some of the people could not give any opinion.

\section{DISCUSSION}

While governments all over the world have announced fiscal measures totaling eight Dollars Trillion to combat the pandemic, the international community has also mobilized funds through international financial institutions to counteract the economic crisis in the most vulnerable countries. In India, also Prime Minister Care Fund (PMCF) was created where in government officials have contributed one day salary apart from contribution made by organized and unorganized sector officials. This fund is being utilized to create better health infrastructure and to help the affected people. The International Monetary Fund (IMF) created a 50 Dollars Billion fund through its rapid-disbursing emergency financing facilities for lowincome and emerging market countries. It has earmarked 10 Dollars Billion to serve its poorest members with a zero-interest rate. Regional banks have also created response facilities aimed at financially supporting their members [33]. The IMF has just revamped the Catastrophe Containment and Relief Trust to offer short-term debt reliefs to some of its member While some SIDS such as Comoros, São Tomé and Príncipe, and the Solomon Islands have already requested and obtained debt relief, there is room for more SIDS to take advantage of this option [Error! Reference source not found.]. Therefore, government help may outweigh the impact of external shocks such as Covid-19 and equip them with the necessary financial resources to plan their next steps for their economic development. By considering the economic impact of reduced tourism revenues and restoring the minimum level of import coverage (three months), it is possible to provide a rough estimate of each country's immediate financial needs to offset the damage of the pandemic.

The Covid-19 is really deadliest pandemic has stopped global economic activities for long time and expected to continue for more time. In such circumstances world production activities suffered a lot particularly those countries where economy is dependent on imports and export The SIDSs islands are more vulnerable in such situation due to their fragile agro ecosystem. These islands are mostly dependent on imports and exports. The trade activities has been suffered a lot due lockdown. The GDP of these islands is going to be very much suffering in terms of continuous decline and resulting in decline of per capita income. Hence, people purchasing power reduced due job/ employment loss. Sustainable development offers high potential for any community within economic, social, cultural, ecologic and physical constraints [33]. Sustainable development goal can only be achieved with the judicious use of 
available resources at SIDS islands. However, its effectiveness depends on an institutional and legal framework that coordinates the initiatives of all sectors, both public and private, to ensure the achievement of common goals through a unified approach. Since A \& N Islands is the strategic location for the country, all precautions need to be taken to protect national and local interests. The air travel is becoming more convenient as many public and private airlines being operated in these islands. However, Covid-19 has stopped all the economic activities and resulting in suffering of people whose dependency is more on tourism sector.

Conclusions and Policy Implications: The tourism industry has always proven to be resilient in times of pandemics and crisis. It is expected that post Covid-19 will not be any different though the road to recovery could be long. With the outbreak of coronavirus and the resultant impact on hotels, the industry is down but not out. Hotel managers must institute a crisis management plan based on the Covid-19 model outlined above to ensure that they keep their heads above water. The tourist inflow to A \& N Islands is increasing over time as explained by time series data during 1995 to 2019. Due to Covid-19 tourist's arrival declined which has serious consequences on the livelihood of islands. With its traditional economic sectors, such as coconut farming and fisheries experiencing a major crisis, the region desperately needs economic reforms. The structural, logistical, and human resources development approaches can counter the ill effect of Covid-19. Harvesting the advantage of Information and Communication Technologies (ICTs), functioning and efficiency of the supply chain management can be increased extensively. For instance, the mobile procurement of perishable commodities can be incentivized [34]. Therefore, this pandemic has offered the new challenges and opportunities and need special attention of the respective government to harness the opportunities in a sustainable manner. The lost revenue and tourist can brought back with policy interventions. The containing measures and restrictions adopted by various countries are likely to intensify the food insecurity. The global food avail-ability and food prices are also affected since the pandemic started to proliferate through various countries. Therefore, Covid19 is main curse to the tourism industry and leading it toward collapsing. It affect all human activities social, religious, cultural and income generating livelihoods. The cancellation of booking of hotels, travel tickets and main programmes and functions indicate the ill effect of pandemic. The higher price of all essentials and short supply posing threat for survival of human beings. In these times of crisis, the world's poorest, who predominantly depend on agriculture, are likely turn out of food. Consequently, hunger, starvation, and malnutrition due to in-adequate and unhealthy feeding habits, put their health and well-being at risk [7],[35]. 
Therefore, tourism sector is going to face more challenges in future to arrive its same path as pre-pandemic. The government support and subsidies like intervention may revive this sector. The findings of this paper will add the information/knowledge for the policy makers and researcher for future action.

Acknowledgement: Authors are thankful to the various researchers who have responded on the Web based question asked. We also thank to various mass media, UNWTO, newspaper editorial writers whose information used in this paper.

Limitation: The research paper is based on the view expressed by various researchers and data reported by various agencies. The interpretation varies from reporter to reporter. Therefore, there may be some bias. It is too early to predict the real impact of pandemic.

Funding: No funding was received for this study. It is based on the interest of the author

Conflicts of interest: Author declaration there is no potential conflict of interest.

\section{REFERENCES}

1. Greenberg,N., Mary Docherty, Sam Gnanapragasam, Simon Wessely. Managing mental health challenges faced by healthcare workers during Covid-19 pandemic, BMJ 2020 Mar 26;368:m1211. doi: 10.1136/bmj.m1211.

2. World Health Organization. Coronavirus Disease (COVID-19): Situation Report139.https://www.who.int/docs/default-source/coronaviruse/situation-reports/20200607Covid-19-sitrep-139.pdf(accessed 10 June 2020).

3. Mental health Foundation. www.mhfindia.org/2020.

4. Gurung D.B. and Scholz R.W.. Community-based Tourism in Bhutan: expert evaluation of stakeholder-based scenarios. Int. J Sust Dev World Ecol., 2008, 15(5):397-411.

5. JianyingXua, Yihe Lu, Liding Chen and Yang Liu. Contribution of tourism development to protected area management: local stakeholder perspectives International Journal of Sustainable Development \& World Ecology, 2009, 16 (1):30-36.

6. Reisinger, Y. \& Mavondo, F. Travel anxiety and intentions to travel internationally: Implications of travel risk perception, Journal of Travel Research, 2005, 43(3):212-25.

7. United Nations/Department of Economic and Social Affairs,. Covid-19 and the Least Developed Countries. Policy Brief. https://www.un.org/development/desa/dpad/ Covid-19 and the least developed countries, 2020.

8. India TV. Covid-19 spread in India breaking news, 2020.

9. GB. Srihat Impact of Covid-19 on Tourism, a report for Asia, Regional Director of Singapore Tourism Board, 2020.

10. Bloomberg. Charting the global economic impact of tourism jobs, https://bloomberg.com/graphics2020.

11. World Travels and Tourism Council. Impact of pandemic on travel and tourism, Retrieved from:https://www.wttc.org/priorities/crisis-preparedness/pandemics/2020.

12. McKibbin, W. Fernando, R. The Global Macroeconomic Impacts of Covid-19: Seven Scenarios (March 2, 2020). CAMA Working Paper No. 19/2020. Retrieved from SSRN: https://paperssrn.com/sol3/papercfm?abstract_id=3547729[Access on March 12, 2020]. 
13. RTE. How the coronavirus may hit the tourism industry, retrieved from https://rte.ie/brainstorm/2020/0303/111987-coronavirus-toruism-ireland.

14. International Air Transport Association: Airlines Financial Monitor January February,2020',Retrieved,from:https://www.iata.org/en/iata-repository/publications.

15. Travel Daily News.Corona virus affecting the tourism industry worldwide, Retrieved from: https://www.traveldailynews.com/post/corona-virus-affecting-the-tourism-industry-13. Worldwide [Access on April 5, 2020].

16. Schmidhuber, J., Pound, J., Qiao, B. Covid-19: Channels of transmission to food andagriculture. Food Agric. Organ, 2020,https://doi.org/10.4060/ca8430en.

17. Endashaw Workiea, Joby Mackolilb, Joan Nyikac and Sendhil Ramadas. Deciphering the impact of Covid-19 pandemic on food security, agriculture, and livelihoods: A review of the evidence from developing countries Current Research in Environmental Sustainability, 2020, 2:100014.http://dx.doi.org/10.1016/j.crsust.2020.100014.

18. Financial Express India. Secondary Agriculture: The Shift Indian Farming Needs.https://www.financialexpress.com/opinion/secondary-agriculture-the-shift-indianfarm-ing-needs/1807044/(accessed 02 September 2020).

19. Nature India. Lessons from a Pandemic to Repurpose India's Agricultural Policy.https://www.natureasia.com/en/nindia/article/10.1038/nindia.2020.83,Accessed date: 10 September 2020.

20. Ishmael Mehsah. Department of Hospitality and Tourism Management, University of Cape Coast, 2020. https://www.hospitalitynet.org/opinion/4098657.html.

21. Patrick Brouder, Simon T, Noel BS. Nart; M., Jessuca M>P, Dimninc L. Freya H.D. Michael $\mathrm{H}$ CMichael $\mathrm{H}$ and Helene Balslev C. Reflection and discussions: Tourism maters in the new normal post Covid-19, Int. Journal of Tourism Geography, (2020).. Https://doi.org/10.1080/14616688.2020.1770325.

22. Subhash Chand, D.R. Singh, Shrawan Singh, R.C. Srivastava, Ajanta Birah, Sairabanu. Vegetables production and role of farmwomen in Andaman and Nicobar Islands, India presented in Global Conference on women in Agriculture at New Delhi, 2012:112.

23. Subhash Chand, Sharwan Singh, Shinoj Parappurathu, S. Dam Roy \&Anjani Kumar. Explaining the status and scope of Tourism development for livelihood security: Andaman and Nicobar Islands, India, International Journal of Sustainable Development \& World Ecology,2015, DOI: 10.1080/13504509.2015. 1050478.

24. Subhash Chand, R.C. Srivastava, P. Krishnan, S. Jaikumar, Ajanta Birah, S. N. Sethi, Nagesh Ram. Impact of Tsunami Rehabilitation Programme for Reviving Livelihood of Affected People of Bay Islands, India 6th National Extension Education Congress, Old Goa, India, 2011,2-5.

25. Jayakumar, S., Arun Kumar Dey, Kundu, A., Kontala Roy, Jaisundar, Kundu, M. S., Balakrishnan, M., Subash Chand, Zamir Ahmed, S.K. Sonographic characteristics of goat testis on water bath based ultrasonography, Livestock science,2013,152:79-87.

26. S. Reddy. Mega tourism in Andaman and Nicobar Islands: Some concerns, J. Hum. Ecolo., 2007,21(3): 231-239.

27. Jurab, P. International-tourism-to-plunge-up-to $30 \%$ fall due to coronavirus UNO Deputy Secretary, https://www.indiatv.in/paisa/business- -698732,_2020.

28. UNWTO Statement on the Containment of Covid-19 [Access on March 29, 2020].

29. Camilli M. The impact of Covid-19 on Italian tourism. Current scenario, opportunity and future tourism organizational strategies, Research article at www.researchgate.net,2020.

30. Statista. Key figures on the impact of coronavirus (Covid-19) on Russian inbound tourism from China in 2020, Retrieved from: https://www.statista.com/statistics/1092398/ russiatourismsector-losses-from-novel-coronavirus-2019ncov/ [Access on March 24, 2020]. 
31. Lewis, Cheung, T.O., and Jim, C.Y. Tourism service preference and management in Hong kong, International Journal of Sustainable Development and World Ecology, 2013,20(2), 182-194.

32. UNWTO Tourism and Covid-19, Retrieved from: https://www.unwto.org /tourism- Covid19 coronavirus [Access on March 29, 2020].

33. Bhuiyan, A.H. Siwar, C. Ismail, S.M. Islam, R. The Role of Tourism for Sustanable Development in East Coast Economic Region (Ecer), Malaysia, an International Journal of Sustainable Development, 2012,3 (9): 53-60.

34. Kumar, A., Padhee, A.K., Kumar, S. How Indian agriculture should change afterCOVID-19. Food Sec. 2020, 12, 837-840.https://doi.org/10.1007/s12571-020-01063-6.

35. Estrada, M., Park, D. \& Lee, M. How A Massive Contagious Infectious Diseases Can Affect Tourism, International Trade, Air Transportation, and Electricity Consumption? The Case of Novel Coronavirus (2019-nCoV) in China (February 19, 2020). Available at SSRN Retrieved from: https://paperssrn.com/sol3/papercfm?abstract_id=3540667.

36. Ayittei, F., Ayittei, M., Chiwero, N., Kamasah, J. \& Dzuvor, C. Economic impacts of Wuhan 2019-nCoV ON China and the world, Journal of Medical Virology, 2020, 92: 473-75.

37. Federazione Italiana del Tourism Coronavirus:Retrieved from: http://www.assoturismo.it/coronavirus-assoturismo-giabruciati-200-milioni-di-euro-diprenotazioni-per-marzo-messina-lavorare-per-la-normalizzazione-osalta-tutto.html,2020.

38. Lee, J.W. and McKibbin, W. Globalization and Disease: The case of SARS, Asian Economic Papers, 2004, 3(1):113-31.

39. Nicholl, A. Personal (non-pharmaceutical) protective measures for reducing transmission of influenza: ECDC interim recommendations. Retrieved from: https://www.ncbi.nlm.nih.gov/pubmed/ 17213533 [Access on March 8, 2020].

40. World Economic Forum. This is how coronavirus could affect the travel and tourism industry, Retrieved from: https://www.weforum.org/agenda/2020/03/world-travel-coronavirusCovid-19jobspandemic-tourism-aviation/[Access on March 20, 2020].

41. BBC News, Coronavirus: 'Extremely serious' concerns on potential tourism impact, Retrieved from https://www.bbc.com/news/uk-northern-ireland-51695480,2020.

42. Khan,K. Arino, J. Calderon, F. Chan, M., Heidebrecht, C., Hu, W., Janes, DA., Macdonald, M., Sears, J., Raposo, P. \& Wang, S. Technical report, Bio. Diaspora project, St. Michael's Hosital Toronto, Canada http:// biodaspora.com/low_res.pdf, 2009.

43. Greeberg N., Coronavirus, anxiety and return to work - how occupational health can make a difference,2020. https://Covid-19.elsevierpure.com/en/clippings/coronavirus-anxiety-andreturn-to-work-how-occupational-health-ca

44. UNWTO/WHO Joint Statement on Tourism and Covid-19 [Access on May 29, 2020].

45. World Food Program, Covid-19 will Double Number of People Facing Food Crises Unless Swift Action is Taken. News Releases. https://www.wfp.org/news/Covid-19 will-doublenumber-people-facing-food-crises-unless-swift-action-taken (accessed 02July 2020).

46. 38. World Travel and Tourism Council. Tourism action plan unleashing India's Potential. Available at http://www.wttcii.org/pdf/India, 2013..

47. Directorate of Economic \& Statistics. Andaman and Nicobar Administrations A \& N Islands. www.aniidco.nic.in, various issues.

48. Forest Statistics Port Blair (India): Department of Environment and Forests, Andaman and Nicobar Administration, various issues.

49. Government of India. National Action Plan for Tourism: Ministry of Civil Aviation and Tourism New Delhi.https://www.who.int/news/item/15-07-2020-who-and-unicef-warn-ofa-decline-in-vaccinations-during-Covid-19.

50. Mass media information indicated. https://www.researchgate.net,2020. 
51. McCoy, A., Norris, A., Saltzer, R. \& Moscardo, G. Changing patterns of regional tourism: implications for tourism on the Great Barrier Reef, Journal of Tourism Studies, 2004, 15 (1): 34-50.

52. Pamela Coke-Hamilton, Impact of Covid-19 on tourism in small island developing states By, Director, Division on International Trade and Commodities, UNCTAD, 2020.

53. The Economic Times Impact of coronavirus on Indian tourism could run into thousands of crores of rupees, retrieved from: https://economictimes.indiatimes.com /industry/services/travel/impact-of-coronavirus-on-indian-tourism-could-run-intothousands-of-crores-of-rupees/articleshow / 74592482.cms? from=mdr [Access on April 5, 2020].

54. World meters Coronavirus Worldwide Graphs, Retrieved from: https://www.worldometerinfo/coronavirus/worldwide-graphs/2020.

55. Park, J.M.; Lee, H.Y.; Park, S.H.; Han, I. Value Relevance of Accounts Receivable Factoring and Its Impact on Financing Strategy under the K-IFRS after COVID-19 from the Perspective of Accounting Big Data. Sustainability 2020, 12, 10287. 